\title{
A (RE)CONSTRUÇÃO DE CONCEITOS BIOLÓGICOS NA FORMAC̣ÃO INICIAL DE PROFESSORES E PROPOSIČ̃̃ DE UM MODELO EXPLICATIVO PARA A RELAC̣ÃO GENÓTIPO E FENÓTIPO'
}

\author{
Lourdes Aparecida Della Justina* \\ Fernanda Aparecida Meglhioratti** \\ Ana Maria de Andrade Caldeira***
}

RESUMO: O objetivo deste trabalho foi investigar as concepções acerca da relação entre genótipo e fenótipo de estudantes da Licenciatura em Ciências Biológicas que integram um grupo de pesquisadores em epistemologia da Biologia. Em uma coleta inicial de dados, ficou evidente a presença de ideias pautadas na relação restrita ao gene e ambiente, sem considerar o organismo e sua história de vida. Entretanto, durante as discussões coletivas acerca desse tema, desenvolveram-se outros conceitos, tais como: interações moleculares; casualidade; organismo; e biologia do desenvolvimento. A análise das (re)construções conceituais que emergiram no grupo possibilitou a elaboração e a proposição de um modelo explicativo para a relação entre genótipo e fenótipo.

Palavras-chave: Epistemologia da Biologia; Formação Inicial de Professores; Genótipo e Fenótipo

THE RECONSTRUCTION OF BIOLOGICAL CONCEPTS IN TEACHER TRAINING AND THE PROPOSITION OF AN EXPLANATORY MODEL FOR THE RELATION BETWEEN GENOTYPE AND PHENOTYPE

ABSTRACT: This paper aims to investigate the conceptions about the relation between genotype and phenotype of Biological Sciences Degree students who take part in a research group in Epistemology of Biology. In an initial data collection, the presence of ideas based on a restricted to genes and environment relation - without considering the organism and its life history - became evident. However, during the group discussions on the topic there were other statements involving other concepts, such as: molecular interactions, chance, organism and Developmental Biology. The analysis of conceptual (re)constructions that emerged in the group allowed the proposition and the development of an explanatory model for the relation between genotype and phenotype.

Keywords: Epistemology of Biology; Teacher Training; Genotype and Phenotype.
*Doutora em Educação para a Ciência pela Universidade Estadual de São Paulo (UNESP).

Professora de Metodologia e Prática do Ensino de Biologia da Universidade Estadual do Oeste do Paraná (UNIOESTE) Email: lourdesjustina@gmail.com

* *Doutora em Educação para a Ciência pela Universidade Estadual de São Paulo (UNESP). Professora do Centro de Ciências Biológicas e da Saúde (Unioeste-Cascavel/PR). Email: meglhioratti@gmail.com

*** Professora do Departamento de Educação da Faculdade de Ciências da Universidade Estadual de São Paulo (UNESP)-Bauru/SP. Email: anacaldeira@fc.unesp.br 


\section{INTRODUC̣ÃO}

O presente artigo é resultado de uma pesquisa realizada pelo Grupo de Pesquisadores em Epistemologia da Biologia de Cascavel-PR (GEBCA), e se insere em uma investigação mais ampla que envolve o estudo de conceitos biológicos e sua abordagem em diferentes contextos do ensino de Biologia. Neste, buscamos contribuir para uma reflexão sobre a relação entre genótipo e fenótipo na perspectiva de uma visão integrada do conhecimento biológico na formação inicial de professores de Biologia.

Os conceitos científicos de genótipo e fenótipo são definições que permeiam o universo acadêmico e escolar. Suas relações de transformação influenciam as representações científicas, a apreensão cultural e social e dimensionam a construção do modo como os seres humanos concebem o fenômeno da vida. Quando o genótipo é concebido apenas como DNA (ácido desoxirribonucleico) e o fenótipo como resultante da interação entre genótipo e ambiente, o desenvolvimento do organismo permanece "esquecido". Ao longo da história da genética no século XX, na delimitação entre genótipo e fenótipo, segundo Gudding (1996), o organismo esteve ausente em uma explicação sistemática dos fenômenos biológicos. Conforme Almeida e El-Hani (2010), o desenvolvimento do organismo é tratado, muitas vezes, na biologia evolutiva e na genética, como uma caixa-preta entre o genótipo e o fenótipo. Assim, o organismo permanece, muitas vezes, à margem do conhecimento biológico, tanto no âmbito da produção da ciência quanto do seu ensino.

Essa perspectiva dificulta a compreensão da Biologia, quer seja na sua construção como ciência, quer seja na sua abordagem no ensino. Para Meglhioratti (2009), o conceito de organismo é integrador do conhecimento biológico. Nessa perspectiva, a compreensão dos conceitos de genótipo e fenótipo depende do estabelecimento de relações entre gene, organismo e ambiente. Entretanto, o organismo e seu desenvolvimento, muitas vezes, não são incluídos nas explicações dos fenômenos biológicos. Assim, há uma limitação do pensamento na ciência biológica, pois o desenvolvimento do organismo permanece como uma caixa preta. Conforme Fourez (1997), trata-se de uma representação que se aceita em sua globalidade sem considerar útil o exame dos mecanismos de seu funcionamento. A fronteira do conhecimento fica restrita ao organismo como um ente passivo, resultante da expressão do genótipo em interação com o meio.

O fato de o desenvolvimento do organismo situar-se em uma rede conceitual como uma caixa-preta constitui um obstáculo epistemológico para a compreensão da ciência biológica. Bachelard (1996) define os obstáculos epistemológicos como inerentes ao processo de conhecimento, os quais se constituem em acomodações ao que já se conhece, podendo ser entendidos como antirrupturas. Os obstáculos podem aparecer na forma de um contrapensamento ou como limitação do pensamento. São encarados como resistências do pensamento ao pensamento. Não são obstáculos externos, como a complexidade e a fugacidade dos fenômenos, nem relativos à fragilidade dos sentidos e do espírito humano. Enfim, é no âmago 
do próprio ato de conhecer que aparecem, por uma espécie de imperativo funcional, lentidões e conflitos.

Acredita-se que a (re)construção conceitual e ampliação de pensamento acerca de conceitos tais como genótipo, fenótipo e desenvolvimento do organismo, no âmbito do ensino, deva começar nos cursos de formação de professores de Biologia. Assim, o objetivo central deste trabalho foi investigar a evolução de ideias acerca da relação genótipo e fenótipo de acadêmicos da Licenciatura em Ciências Biológicas em momentos privilegiados de discussão de epistemologia da Biologia, junto ao GEBCA.

Iniciamos este trabalho com uma breve exposição acerca dos conceitos de genótipo e fenótipo, na perspectiva da biologia sistêmica, e as possíveis implicações de (des)considerar o desenvolvimento do organismo para a compreensão da relação genótipo e fenótipo. Também fazemos uma breve reflexão acerca desses conceitos no contexto do ensino de Biologia, em especial na formação de professores. Em seguida, apresentamos e discutimos alguns trechos de falas e diálogos de estudantes durante as atividades do GEBCA, na tentativa de demonstrar a sua (re)construção de conceitos biológicos. Como alternativa, propomos um modelo explicativo para a rede conceitual necessária à compreensão da relação entre genótipo e fenótipo de forma sistêmica, modelo que pode ser utilizado e refletido no ensino de Biologia.

\section{GENÓTIPO, FENÓTIPO E O DESENVOLVIMENTO DO ORGANISMO}

A visão tradicional das relações inerentes ao sistema genótipo-fenótipo se baseia na ideia de que os seres vivos são considerados como produtos da interação entre o genótipo e o fenótipo, sendo o genótipo considerado o conjunto de genes e o fenótipo a expressão de características no organismo decorrente da relação entre seus genes e o ambiente. Nessa perspectiva, o organismo é fruto passivo da interação entre seus genes e o ambiente no qual se encontra. Essa ideia está presente em livros utilizados na formação de biólogos licenciados, como, por exemplo, em Griffiths et al. (2002).

De acordo com Justina et al. (2010), os conceitos de genótipo e fenótipo foram propostos por Wilhelm Ludwig Johannsen (1857-1927), no início do século XX, como forma de facilitar a comunicação entre os pesquisadores daquela época. Wilhelm L. Johannsen afirma:

[...] vou propor os termos "gene" e "genótipo" e mais alguns termos, como "fenótipo" e "biótipo", a serem utilizados na ciência da genética. O "gene" é uma palavra muito pouco aplicável, facilmente combinado com outros, e, portanto, pode ser útil como uma expressão para a "unidade de fatores", "elementos" ou "alelomorfos" nos gametas, utilizadas por modernos pesquisadores mendelianos. O "genótipo" é a soma de todos os "genes", em um gameta ou em um zigoto [...] Todas as características de organismos, distinguíveis por inspeção direta da aparência ou por descrição dos métodos de medição,

Revista Ensaio | Belo Horizonte | v.14 | n. 03 | p. 65-84 | set-dez | 2012 
poderão ser caracterizadas como "fenótipo". [...] Quanto à natureza dos "genes” não é de valor propor alguma hipótese, mas a noção de "gene" abrange uma realidade que é evidente a partir do Mendelismo. Os mendelianos têm o grande mérito de serem prudentes em suas especulações. Em completo acordo com essa limitação - uma reação natural contra a especulação morfológica fantástica da escola de Weismann - poderia ser enfaticamente recomendado o uso do termo adjetivo genotípico ao invés do nome genótipo. Nós não conhecemos um "genótipo", mas somos capazes de demonstrar diferenças ou semelhanças genotípicas. Utilizados desta maneira, os termos "gene" e "genótipo" não seriam prejudiciais (JOHANNSEN, 1911, p. 133).

No contexto de sua proposição, o conceito de genótipo, para Johannsen, assumiu diferentes significados, passando de um conceito abstrato de natureza instrumental, proposto para expressar a regularidade da transmissão de caracteres fenotípicos em cruzamentos, para possíveis entidades causais, reais, que corresponderiam aos genes e, ao final, como o conjunto de processos fisioquímicos.

Atualmente, a definição de genótipo mais frequentemente encontrada em dicionários e em livros didáticos, e ainda aceita pelos geneticistas, é a "soma de todos os genes", embora em determinado enquadramento conceitual sobre o que é gene. Em busca de um alargamento conceitual, pergunta-se: o que é considerado um gene?

A visão clássica do gene, prevalecente durante as décadas de 1910 a 1930, apresentava o gene como a unidade indivisível de transmissão, recombinação, mutação e função genéticas. Somente no início da década de 1940, com a descoberta da recombinação intragênica, houve a formulação do neoclássico conceito do gene, que prevaleceu até a década de 1970. As descobertas da tecnologia do DNA, no início dos anos 1970, levaram à segunda revolução no conceito do gene. Assim, apesar de a compreensão da estrutura e organização do material genético ter avançado muito, ainda na atualidade, conforme Portin (2002), o conceito geral do gene e, consequentemente, de genótipo, permanece em aberto, sendo adotado de formas diversas pelas diferentes áreas das ciências biológicas.

No presente artigo, a opção é pela definição de gene molecular processual que se aproxima do conhecimento biológico atual, no qual o gene é um processo (i. e., o curso de eventos) que liga o DNA e todas as outras entidades relevantes que não estão no DNA na produção de um polipeptídio particular. Nesse sentido, o termo gene é apoiado por processos que são relacionados por (1) interações específicas entre o segmento do DNA e entidades não localizadas no DNA, (2) mecanismos de processamento específicos dos mRNAs resultantes, em adição a interações com entidades não localizadas no DNA. Esses processos, em sua ordem temporal específica, resultam (3) na síntese de um polipeptídeo específico. Este conceito de gene é relacional e sempre inclui interações entre o DNA e seu ambiente (desenvolvimento) (NEUMANN-HELD, 2001). Diante do exposto, percebe-se a necessidade de reformulação do conceito de gene e, consequentemente, de genótipo e fenótipo, nos diferentes lócus de ensino em que são abordados.

Uma forma de trazer ao debate a rede conceitual atualizada acerca da relação genótipo e fenótipo para o cerne da discussão teórica da biologia é compreender tal relação a partir de uma "teoria sistêmica do desenvolvimento", destacando a 
complexidade e a multiplicidade de fatores envolvidos no desenvolvimento orgânico e o organismo como uma totalidade que age e transforma o seu ambiente. Desse modo, para desenvolver uma abordagem da relação genótipo e fenótipo de acordo com uma teoria sistêmica do desenvolvimento, é importante destacar alguns pressupostos nos quais essa teoria se apoia. Oyama, Griffiths e Gray (2001) entendem que, na explicação do desenvolvimento mediante uma perspectiva sistêmica, são considerados os seguintes pontos: (1) determinação por múltiplas causas, estando todo traço configurado pela interação de muitos recursos do desenvolvimento, sendo a dicotomia gene/ambiente apenas um dos muitos recursos; (2) a significância de qualquer causa é contingente em relação ao restante do sistema; (3) a herança é ampliada, considerando que um organismo herda uma ampla variedade de recursos que interagem na construção do ciclo de vida de um organismo; (4) o desenvolvimento é entendido como construção, pois nenhum traço ou representações de traço são transmitidos nas gerações, ao invés disso, são construídos/ reconstruídos no desenvolvimento; (5) o controle é distribuído, nenhum dos interagentes específicos controla o desenvolvimento; (6) a evolução é uma construção, na qual não se entende que organismos ou populações são moldados pelo ambiente, mas que o sistema organismo-ambiente muda ao longo do tempo. Cabe, então, questionar como se configuram os conceitos de genótipo e fenótipo a partir dos pressupostos para a construção de uma teoria sistêmica do desenvolvimento.

Embora atualmente exista predominância dos reducionismos DNA-cêntrico e ambiental nas explicações dos processos biológicos, essas visões começaram a ser desafiadas já na segunda metade do século XX, sendo os debates acentuados no final do mesmo século. Os desafios foram colocados principalmente ao conceito de gene, não sendo possível manter a ideia do gene como uma unidade de estrutura e função, devido a uma maior compreensão da dinâmica celular e da expressão gênica e a identificação de processos (splicing alternativo, genes interrompidos, edição de mRNA, etc.) que não permitem uma correlação direta entre uma sequência de DNA e um determinado polipeptídeo. Também no âmbito da teoria da evolução, buscou-se integrar as abordagens da biologia do desenvolvimento, configurando a perspectiva evo-devo. Nesta perspectiva, concebe-se que a compreensão da Biologia perpassa pelo entendimento das teorias do desenvolvimento. Há uma preocupação em se recuperar o organismo como totalidade, como unidade autônoma que age em seu ambiente, entendendo as interações internas de maneira sistêmica, sendo estas dependentes de uma multiplicidade de fatores (MEGLHIORATTI, 2009).

Griffiths e Gray (2001, p. 195) argumentam que em uma teoria sistêmica do desenvolvimento, as diferenças empíricas entre o papel do DNA e outros recursos do desenvolvimento não justificam a distinção metafísica construída sobre eles, ou seja, o DNA é apenas mais um dos recursos que o organismo utiliza em seu desenvolvimento, não tendo supremacia sobre os outros fatores que interagem no desenvolvimento do organismo. Nesse contexto, os autores entendem que o conceito de herança é utilizado para explicar a estabilidade da forma de 
uma geração à outra, considerando como herança biológica todo recurso que permanece presente em sucessivas gerações e que é parte da explicação sobre o porquê de cada geração se assemelhar à anterior. Jablonka (2001, p. 100) destaca diferentes sistemas de transmissão de herança, entendendo como transmissão todo o processo que leva à regeneração de algum tipo de estado, organizado ao longo das gerações. Isso inclui a transferência direta de recursos e as atividades que levam à reconstrução de um fenótipo ancestral.

Essa interpretação de herança está associada à ideia de que o organismo não recebe todas as características ou traços fenotípicos prontos ou codificados em uma molécula do DNA, sendo estes traços ou características construídos e/ou reconstruídos ao longo do desenvolvimento orgânico, pela interação de uma multiplicidade de fatores. Os elementos e redes de interações hereditárias presentes na célula-ovo funcionam como indicativos do desenvolvimento para o próximo momento, ou seja, como apontam Oyama, Griffiths e Gray (2001, p. 5), "o caminho pelo qual um organismo se desenvolve funciona como um recurso para seu próprio desenvolvimento futuro”. Embora os indicativos de desenvolvimento presentes na célula-ovo apresentem certa estabilidade (no sentido de que é mantido pelo menos por algumas gerações), as características expressas pelo organismo ao longo de sua vida estão presentes apenas como potencialidade, necessitando ser construída e/ou reconstruída durante a vida de um organismo. Os recursos herdados, constituindo-se como indicativos do desenvolvimento, podem ser de diferentes tipos: sequências de DNA; sistemas estáveis baseados em ciclos de retroalimentação autossustentável; estruturas celulares que são usadas como guia ou molde para a construção de estruturas similares; marcas da cromatina que afetam a expressão gênica; entre outros (JABLONKA, 2001; JABLONKA; LAMB, 2005).

Nesse sentido, em uma abordagem sistêmica do desenvolvimento o genótipo é flexível e pode ser considerado como o conjunto de indicativos do desenvolvimento, interno ao organismo, que permitem a sua construção em caminhos nos quais ele se assemelhe às gerações anteriores - genótipo potencial. O fenótipo corresponde às características aparentes de um organismo em um determinado momento do desenvolvimento, fruto das interações entre herança genotípica, aspectos aleatórios do desenvolvimento, herança ambiental, aspectos aleatórios do ambiente e ação do organismo sobre seu meio.

No âmbito do ensino de Biologia, considera-se imprescindível que os estudantes tenham acesso aos conceitos biológicos atualmente aceitos pela comunidade científica e que o conhecimento seja trabalhado de forma integrada. Em relação ao ensino na área da genética, observa-se a existência de um discurso mais próximo do determinismo genético (JUSTINA; FERRARI, 2010) e/ou reducionismo ambiental, distanciando-se de uma abordagem sistêmica. Neste sentido, na sequência, serão abordadas algumas reflexões quanto à construção conceitual na área de genética no âmbito da formação inicial de professores de Biologia. 
A (re)construção de conceitos biológicos na formação inicial de professores

\title{
3. A NECESSÁRIA (RE)CONSTRUC̣ÃO CONCEITUAL NA FORMAC̣ÃO INICIAL DE PROFESSORES
}

Investigações realizadas acerca do ensino e aprendizagem de genética têm evidenciado algumas dificuldades tanto por parte de alunos como por professores em relação a questões referentes a conceitos biológicos na área de genética (BONZANINI, 2011; ANDRADE, 2011, entre outros). No que se refere ao contexto da formação inicial de professores de Ciências e Biologia, essas dificuldades se devem tanto à complexidade dos conceitos que essa área comporta quanto à forma de os professores conceberem, organizarem e desenvolverem o ensino. Pesquisas realizadas sobre a percepção de conceitos em genética em diferentes níveis de ensino apontaram uma incipiente compreensão destes. Schneider et al. (2011) realizaram investigação acerca do conceito de gene com professores formadores da Licenciatura em Ciências Biológicas, e evidenciaram, na maioria das vezes, uma visão molecular clássica. Andrade (2011), em estudo com licenciandos em Ciências Biológicas sobre expressão gênica, salientou que a visão molecular constitui-se em obstáculo epistemológico para a (re)construção conceitual. Autores como Justina e Ferrari (2010) indicam que o entendimento de conceitos básicos de genética é essencial para a compreensão das novas tecnologias e avanços desta ciência. No que se refere aos professores e o ensino de Biologia, conforme Trivelato (1995, p. 44):

\begin{abstract}
Qualquer que seja a orientação adotada, o domínio e a segurança em relação aos conteúdos permite ao professor a percepção do que é fundamental e do que é supérfluo, do que é generalizável e do que é particular [...] do que está interligado a outras áreas [...] quando o docente não conhece profundamente o tópico que desenvolve com os alunos [...] age de forma superficial, procurando formalizações, enfatizando a memorização, desviando-se de situações que representem aplicações desse conhecimento, evitando assim, modalidades didáticas que suscitem dúvidas e questionamentos pelos alunos.
\end{abstract}

Nesse panorama, a realização do trabalho docente de ensinar, para Tardif (2002), implica, além de certos conhecimentos relativos às ciências da educação e à pedagogia, no desenvolvimento de um saber prático baseado em sua experiência cotidiana com os alunos, também no conhecimento de sua matéria, sua disciplina e seu programa. Conforme Perrenoud (2000, p.27):

A competência requerida hoje em dia é o domínio dos conteúdos com suficiente fluência e distância para construí-los em situações abertas e tarefas complexas, aproveitando ocasiões, partindo dos interesses dos alunos, explorando os acontecimentos, em suma, favorecendo a apropriação ativa e a transferência de saberes, sem passar necessariamente por uma exposição metódica, na ordem prescrita por um sumário. Essa facilidade na administração das situações e dos conteúdos exige um domínio pessoal [...] os conceitos, as questões e os paradigmas que estruturam os saberes no seio de uma disciplina. Sem esse domínio, a unidade de saberes está perdida, os detalhes são superestimados e a capacidade de reconstruir um planejamento didático a partir dos alunos e dos conhecimentos encontra-se enfraquecida. 
Como consequência da falta de conhecimento da área biológica, para Cunha (2001) o professor resiste a mudar sua prática principalmente em conteúdos que não domina. Portanto, se queremos mudar a prática do professor quanto ao ensino de genética, precisamos melhorar o seu conhecimento científico específico. Nesse sentido, as licenciaturas em Ciências Biológicas não podem prescindir de atividades que possibilitem uma forte base conceitual da Biologia. Carvalho e Gil-Pérez (2009, p.21) enfatizam a relevância de abordar o conteúdo científico como uma necessidade formativa, ao apontarem para a "gravidade de uma carência de conhecimentos da matéria, o que transforma o professor em um transmissor mecânico dos conteúdos do livro de texto".

Face aos avanços científicos e tecnológicos e as dificuldades no ensino da área de genética, é imprescindível que a formação inicial de professores proporcione aos estudantes uma visão sistêmica dos seres vivos, em que a molécula de DNA seja concebida como um componente, entre outros, na intrincada rede de interações celulares e orgânicas. Na perspectiva de formação inicial voltada, entre outros fatores, para a construção dos conceitos biológicos, a seguir apresentamos e discutimos um estudo realizado junto a um grupo de epistemologia como lócus de (re)construção conceitual na área de genética.

\section{4. $O$ DESENVOLVIMENTO DA PESQUISA}

A presente investigação está inserida em uma pesquisa mais ampla junto a um grupo de pesquisadores que estudam história e filosofia da Biologia, denominado Grupo de Pesquisadores de Epistemologia da Biologia de Cascavel/PR (GEBCA). Este grupo está vinculado ao Grupo de Pesquisa em Educação em Ciências e Biologia - GECIBIO, constituído por graduandos, pós-graduandos e docentes da Universidade Estadual do Oeste do Paraná. No GEBCA são realizados estudos e investigações acerca da história, epistemologia e ensino da Biologia, desde maio de 2009. Trata-se de um grupo voltado para a formação de biólogos licenciados (pesquisadores e professores), tendo como aporte teórico aspectos históricos e epistemológicos do conhecimento biológico. A metodologia adotada no grupo, durante os encontros semanais, é a problematização de conceitos científicos da Biologia e o estabelecimento de entrelaces com suas abordagens no âmbito do ensino, tanto na formação inicial de professores, como na educação básica, como em meios de divulgação científica.

Esta pesquisa centrou-se em três momentos principais. No primeiro momento, os dados foram coletados mediante questões-problema escritas, referentes à relação entre gene e organismo, entre organismo e ambiente, ao estudo das partes e todo, causas e efeitos, e sobre as direções no estudo da Biologia.

Em um segundo momento, houve uma discussão coletiva sobre as questões-problema, com base em ideias de Lewontin (2002). Embora a obra $A$ tripla bélice: gene, organismo e ambiente não faça referência direta aos conceitos da relação 
entre genótipo e fenótipo, esta foi escolhida para discussão no GEBCA por enfocar conceitos essenciais, de forma integrada, para o entendimento dessa relação que são: gene, organismo e ambiente. O estudo foi vídeo gravado, constituindo-se em entrevista em grupo. Segundo Flick (2009), os sujeitos entrevistados expõem mais seu ponto de vista em uma situação de entrevista com um planejamento aberto do que em um questionário fechado. Tanto no primeiro como no segundo momento a amostra foi constituída por 11 acadêmicos (A1-A11). No segundo momento, houve a mediação por duas pesquisadoras (M1 e M2).

No terceiro momento, as discussões foram transcritas e os dados tabulados. Os dados analisados são os que se referem à relação genótipo e fenótipo, ao papel atribuído ao organismo nessa relação e se houve (re)construção conceitual durante o desenvolvimento das discussões no GEBCA. Para a análise dos dados, foram elaboradas categorias, seguindo a abordagem da pesquisa qualitativa e procurando investigar em profundidade as respostas dos acadêmicos ao questionário e seus discursos ao longo das discussões no grupo. A análise qualitativa por meio de categorias é considerada por Flick (2009) um método apropriado para a interpretação dos dados, sendo fragmentos de falas interpretados e organizados em categorias inferidas dos próprios dados, mediante a percepção de certos padrões de respostas. $\mathrm{O}$ foco da análise foi norteado por três eixos de discussão e suas respectivas categorias de análise (Quadro 1), os quais foram elencados após a pré-análise dos dados.

Quadro 1: Eixos e categorias de análise dos dados

\begin{tabular}{|l|l|}
\hline Eixos de discussão & Categorias \\
\hline $\begin{array}{l}\text { O desenvolvimento do organismo como } \\
\text { caixa-preta na relação genótipo e fenótipo }\end{array}$ & $\begin{array}{l}\text { Determinismo genético } \\
\text { Genótipo + ambiente = fenótipo }\end{array}$ \\
\hline $\begin{array}{l}\text { O organismo como parte ativa da relação } \\
\text { genótipo e fenótipo }\end{array}$ & $\begin{array}{l}\text { Inclusão do organismo } \\
\text { Estabelecimento de relações entre } \\
\text { organismo, genótipo e ambiente }\end{array}$ \\
\hline A (re)construção de conceitos biológicos & $\begin{array}{l}\text { Fragmentação } \\
\text { Integração de conceitos }\end{array}$ \\
\hline
\end{tabular}

O eixo de análise acerca do "desenvolvimento do organismo como caixa-preta na relação genótipo e fenótipo" refere-se à ideia de organismo como ente passivo nas discussões do GEBCA. Neste, são discutidas, com a apresentação de exemplos de enunciados dos estudantes, as categorias "determinismo genético" e "genótipo + ambiente $=$ fenótipo". Na primeira categoria atribui-se ao gene e/ou DNA o papel principal nos processos biológicos. Na segunda, atribui-se a interação entre genótipo e o ambiente à determinação do fenótipo.

No segundo eixo, que trata do organismo como parte ativa da relação genótipo e fenótipo, são discutidos enunciados em que os estudantes participantes 
da amostra incluem o termo "organismo" nas discussões. Na primeira categoria são considerados os enunciados em que se passa a falar sobre o organismo, mas sem estabelecer relações com outros níveis (externo e interno). Na segunda, são colocados os enunciados nos quais emergem relações entre o organismo e seu meio externo (ambiente) e interno (célula, organelas, gene, etc.).

O terceiro eixo, "a (re)construção de conceitos biológicos", refere-se a entrelaces entre a metodologia problematizadora de conceitos utilizada no GEBCA e a abordagem desses conceitos em outros âmbitos da formação inicial de professores. Nesse eixo, são discutidos exemplos de enunciados de participantes do GEBCA acerca do estudo de conceitos biológicos realizados no âmbito de sua formação inicial como professores. Na primeira categoria foram destacados pelos participantes momentos em que os conteúdos possuem uma abordagem fragmentada; na segunda, são citados momentos em que ocorre a integração de conceitos facilitando o entendimento do conhecimento biológico.

\section{RESULTADOS E DISCUSSÃO}

\subsection{0 desenvolvimento do organismo como caixa-preta na relação entre genótipo e fenótipo}

$\mathrm{Na}$ análise dos questionários e também nas ideias emitidas inicialmente nas discussões no grupo quanto à relação gene e organismo, no que se refere às "diferenças entre os organismos da mesma espécie", nas respostas dos 11 participantes foi evidenciada uma visão condizente com a categoria "determinismo genético”, corroborando o apontado por autores como Justina e Ferrari (2010), por exemplo, nas respostas de A7 e A8:

A diferença entre os indivíduos se deve à recombinação genética no crossing-over que ocorre entre as células na meiose. (A7)

A função da orelha pode ser respondida estudando [...] genes. (A8)

O determinismo genético se constitui como um obstáculo epistemológico, em termos bachelardianos, para a compreensão da relação entre genótipo e fenótipo na ampliação do pensamento em direção a uma compreensão da complexidade dos fenômenos biológicos. No contexto de ensino, fornece a mesma resposta para todas as questões, tudo se justifica em termos de genes, não são consideradas as condições individuais de um organismo e seu ambiente. Não foram evidenciadas respostas condizentes com o reducionismo ambiental, em que o ambiente sozinho determina o fenótipo. Também na análise dos questionários, ficou evidente a presença da ideia de que o fenótipo é resultante da relação entre gene e ambiente, desconsiderando o desenvolvimento do organismo, como no caso da fala de A1:

Tanto as diferenças como as similaridades são determinadas pelo DNA [...] e pelo ambiente. (A1) 
A análise dos resultados do questionário evidenciou a presença, em oito (A1; A3; A4; A5; A7; A8; A9; A11) dos onze questionários, de ideias pautadas na relação restrita à categoria "genótipo+ambiente = fenótipo", sem considerar o organismo e sua história de vida, constituindo-se como obstáculo epistemológico para a compreensão dos processos biológicos de forma sistêmica. No âmbito do ensino, constata-se que quando os alunos se referem aos conceitos, como por exemplo "o fenótipo é o resultado da interação genótipo e ambiente", parece que isso é suficiente para definir os conceitos, sem necessidade de abertura das caixas-pretas referentes ao assunto. Considerar o organismo como ente passivo na relação genótipo e fenótipo pressupõe que este é apenas um meio de expressão do genótipo em interação com o ambiente. É uma limitação do pensamento que leva a acreditar no mito do inevitável, do determinismo genético e/ou reducionismo ambiental.

Durante o século XX, com o enfoque reducionista das pesquisas em Biologia, houve um "esquecimento do corpo", ou seja, do todo/organismo (GUDDING, 1996). A visão reducionista do conhecimento biológico embasou a abordagem da Biologia no âmbito do ensino no século passado e continua a nortear, muitas vezes, os currículos de formação de professores e da educação básica. Uma forma de integrar os conceitos biológicos, como afirmam Meglhioratti, El-Hani e Caldeira (2009), é colocar o organismo como um dos conceitos estruturantes da Biologia.

\subsection{0 organismo como parte ativa da relação genótipo e fenótipo}

Neste tópico, serão analisados os diálogos estabelecidos entre os participantes no coletivo do GEBCA, não de forma individual, pois alguns licenciandos mantiveram-se em silêncio em parte das discussões, não sendo possível evidenciar o desenvolvimento de suas percepções quanto à relação genótipo e fenótipo. No início das discussões, evidenciou-se a primeira categoria "inclusão do organismo". Somente com o decorrer das discussões houve evidências da segunda categoria, "estabelecimento de relações entre organismo, genótipo e ambiente", como exposto na sequência.

Durante as discussões iniciais da obra de Lewontin (2002) no GEBCA, verificou-se que, houve uma aproximação à ideia de que o organismo passa a ser considerado como parte ativa da relação genótipo e fenótipo com a inclusão deste de forma gradativa por parte dos participantes, o que corrobora os resultados relatados por Andrade (2011) em sua investigação com um grupo de licenciandos. Inicialmente, não houve o estabelecimento de relações, ou seja, a abertura dessa caixa-preta, como pode ser exemplificado na fala de A6:

[...] mas se não está relacionado a material genético, então já me perdi, se não é ambiente, se não é gene $[. .$.$] então são coisas do próprio organismo? (A6)$

$\mathrm{Na}$ sequência, os licenciandos foram questionados acerca da variação no número de cerdas de um lado para outro de uma drosófila. Inicialmente, a resposta foi a associação a fatores genéticos, ao ambiente e, após, às interações entre os 
constituintes celulares. Também ficou evidente o interesse de participantes do grupo de buscar entender como acontece essa relação entre genótipo, fenótipo e desenvolvimento de um organismo foco. Nesse momento, percebeu-se que além da inclusão do organismo nas problematizações no coletivo do grupo, houve o início da abertura da caixa-preta sobre o desenvolvimento do organismo, quando estudantes começaram a estabelecer relações com outros conceitos como ruídos do desenvolvimento:

A11: [...] seres com o mesmo genótipo em um mesmo ambiente podem ter variações fenotípicas, né? E isso se deve a ruídos de desenvolvimento, uma coisa assim, são acho que as alterações. [...]

A1: Então é o gene que está se expressando de forma diferente?

M2: [...] mas o que leva o gene a se expressar diferente?

A1: [...] as interações dentro da célula.

M1: E o que interage dentro da célula?

A1: Tudo! Todas as organelas: os ribossomos [...]

A7: Os ruídos ali [...]

M2: O que são esses ruídos do desenvolvimento?

A6: Casualmente, tem o mesmo material genético, eles conseguem responder de formas diferentes como A7 falou [...] a resposta individual.

M1: Casualmente aonde em que local?

A6: Dentro do organismo.

A1: [...] por que o material de dentro da célula é diferente de uma para outra.

Nos enunciados acima, há evidências de (re)construção do conhecimento biológico pelos participantes, como é o caso de A1, A6 e A11, quando, nas discussões do GEBCA, emitiram falas envolvendo conceitos não presentes em seu questionário inicial, tais como: ruídos de desenvolvimento; resposta individual; casualidade; e organismo.

Para verificar o estabelecimento de relações pelos estudantes, foi problematizada a metáfora "tripla hélice: gene, organismo e ambiente". Percebeu-se que houve a inclusão do organismo nas discussões coletivas do grupo e, ao mesmo tempo, a relação com outros conceitos como gene e ambiente, conforme pode ser observado nos diálogos abaixo, por parte de A4 e A7:

M1: $\mathrm{Na}$ opinião de vocês o que o autor quer dizer com a metáfora da tripla hélice, ao se referir a gene, organismo e ambiente?

A4: Ele quis dizer que é um conjunto de coisas que vai formar a vida [...] que esses três fatores são importantes.

A7: Eu entendi que ele coloca a tripla hélice não se referindo à dupla hélice do DNA [...] não é só o gene, o DNA que determina as características do organismo. É o gene, o organismo e o ambiente que são responsáveis pelas mudanças e pelas características do organismo e do ambiente, uma coisa assim tripla, não só uma sátira, mas uma crítica à dupla hélice.

Nesse sentido, comparando enunciados emitidos nos questionários e durante as discussões da obra de Lewontin, por participantes da amostra investigada, 
observa-se a inclusão de novos conceitos, conforme exemplos de enunciados, emitidos por A1, A3 e A5 (Quadro 2).

Quadro 2: Exemplos de enunciados emitidos por participantes para uma mesma questão-problema de forma escrita (primeiro momento) e durante as discussões no grupo (segundo momento)

\begin{tabular}{|c|c|c|}
\hline Questão & Primeiro Momento & Segundo Momento \\
\hline $\begin{array}{l}\text { 1. A que se deve as } \\
\text { similaridades e diferenças } \\
\text { entre indivíduos da mesma } \\
\text { espécie? E no caso } \\
\text { dos clones? }\end{array}$ & $\begin{array}{l}\text { A1: Tanto as similaridades } \\
\text { quanto as diferenças são } \\
\text { determinadas pelo DNA } \\
\text { (espécies próximas ou } \\
\text { distantes) e pelo ambiente. } \\
\text { No caso dos clones que } \\
\text { possuem DNA igual [...] fica } \\
\text { mais visível que também } \\
\text { o ambiente interfere nas } \\
\text { características. }\end{array}$ & $\begin{array}{l}\text { A1: A gente sempre } \\
\text { lembra do DNA e depois } \\
\text { do ambiente, e agora vejo } \\
\text { que as três coisas (gene, } \\
\text { organismo e ambiente) } \\
\text { são os responsáveis pelas } \\
\text { mudanças e características } \\
\text { do organismo e do } \\
\text { ambiente. E não que tudo é } \\
\text { determinado pelo DNA. E os } \\
\text { gêmeos nem são assim } \\
\text { tão idênticos. }\end{array}$ \\
\hline $\begin{array}{l}\text { 2. Por que as estruturas } \\
\text { que crescem nas laterais de } \\
\text { nossa cabeça têm o formato } \\
\text { de orelhas e não de pés? }\end{array}$ & $\begin{array}{l}\text { A3: É assim por questões } \\
\text { pré-determinadas, pelo } \\
\text { ambiente, genes, por } \\
\text { cada espécie ter suas } \\
\text { características próprias e os } \\
\text { fatores limitantes. }\end{array}$ & $\begin{array}{l}\text { A3: [...] além dos genes, eu } \\
\text { acredito que a orelha está } \\
\text { no lugar da orelha e não } \\
\text { do pé e tem esse formato é } \\
\text { por questão embriológica } \\
\text { mesmo, porque lá no início } \\
\text { as divisões de célula e } \\
\text { tudo mais e a partir disso } \\
\text { [...] células pluripotentes } \\
\text { e tudo mais, elas têm uma } \\
\text { determinada função [...] em } \\
\text { determinado ambiente tem } \\
\text { hormônios ou alguma coisa } \\
\text { assim [...] é um processo } \\
\text { de sinalização [...]. }\end{array}$ \\
\hline $\begin{array}{l}\text { 3. } 0 \text { que Lewontin quer dizer } \\
\text { com a metáfora da "tripla } \\
\text { hélice" ao se referir a gene, } \\
\text { organismo e ambiente? }\end{array}$ & $\begin{array}{l}\text { A5: Todos os três constituem } \\
\text { o organismo. }\end{array}$ & $\begin{array}{l}\text { A5: [...] lendo o texto você não } \\
\text { consegue mais responder } \\
\text { a estas questões. Porque } \\
\text { ele fala que a evolução não } \\
\text { é mais aceita e é um fator } \\
\text { limitante para pensamentos } \\
\text { mais avançados. E fala } \\
\text { que não é só o gene, nem } \\
\text { só o ambiente, nem só o } \\
\text { organismo que vai estar } \\
\text { relacionado, então você } \\
\text { tenta responder com o } \\
\text { conhecimento que você } \\
\text { tem, mas você vê que não } \\
\text { tem resposta [...]. }\end{array}$ \\
\hline
\end{tabular}


Na questão 1, o estudante A1 emite, no primeiro momento, uma visão de organismo como mera expressão do genótipo em interação com o meio, portanto, um ente passivo; e (re)construindo sua visão, em um segundo momento, inclui o organismo como ativo na relação. Em relação à questão 2, pode-se inferir que houve a (re)construção de conceitos por A3, no momento em que começa a estabelecer relações entre genótipo e desenvolvimento do organismo, ultrapassando a visão limitada do fenótipo como resultado da interação entre genótipo e ambiente. Verifica-se, também, a ciência da limitação dos conhecimentos construídos e a necessidade de novas construções, como salienta A5 na questão 3, ao perceber que não consegue explicar as relações entre gene, organismo e ambiente.

O conhecimento biológico deve ser tratado, na licenciatura em Ciências Biológicas, de forma menos fragmentada e reducionista. Uma forma de se realizar isso é a problematização de conceitos e a sua retificação. Não basta inserir novos termos/nomenclaturas e deixá-los como caixas-pretas, é preciso reconstruí-los em redes conceituais para vencer as limitações de pensamento. Nessa perspectiva, no próximo item serão discutidos alguns pontos referentes ao enfoque do conhecimento biológico na formação de professores.

\subsection{A (re)construção de conceitos biológicos na formação inicial de professores}

Ao pensar a necessidade de que nos cursos de formação de professores de Biologia, os saberes dos conteúdos específicos da área biológica devam ser construídos pelos alunos (CARVALHO, GIL-PÉREZ, 2009; PERRENOUD, 2000; TRIVELATO, 1995) em uma perspectiva de constante retificação (BACHELARD, 1996), a abordagem por meio de conceitos biológicos problematizados se apresenta como um instrumento potencializador de tal construção, no sentido de ultrapassar as limitações do pensamento acerca da visão fragmentada/reducionista do conhecimento biológico na formação de professores.

No pensamento de membros da amostra investigada, como é o caso de A5, as discussões do grupo deveriam ser estendidas a outros alunos do curso, como forma de superar a fragmentação do conhecimento biológico presente nos cursos de formação:

\footnotetext{
As questões que temos aqui deveriam ser apresentadas a outros colegas do curso e também aos professores, pois a minha forma de pensar a Biologia mudou muito desde que comecei no grupo. Antes eu via uma matéria de cada vez, agora tento pensar nelas juntas para entender como os fenômenos ocorrem. (A5)
}

Esse apontamento corrobora com indicativos presentes na literatura de autores como Loreto e Sepel (2006), de que os professores formadores evitam ordenar e conduzir discussões sobre temas complexos e polêmicos em genética nos cursos de graduação. Nessa direção, o participante A7 sugere que no curso de graduação em Ciências Biológicas, os conteúdos deveriam ser tratados de forma integrada, como fica evidente em sua fala: 
Eu acho que deveria ser uma coisa mais conjunta a biologia celular com embriologia, histologia, uma coisa mais ampla, não separadinho assim, porque daí [...] fica sem sentido para entender o ser vivo. (A7)

No GEBCA, ao se ter como ponto inicial de problematização a relação entre diferentes conceitos biológicos, percebe-se que, no decorrer das discussões, elementos como o ensino e a produção científica são colocados em evidência, como pode ser constatado nas falas elencadas acima. Salienta-se, assim, que o conhecimento biológico pode e deve ser o desencadeador de problematizações que levem à construção de saberes docentes tanto de cunho biológico como didático-pedagógico, na formação inicial de professores de Biologia. Concordando com Pedrancini, Corazza e Galuch (2011), o ensino voltado para o desenvolvimento da abstração, generalização e formação de conhecimentos científicos não deve ser apenas direcionado para a definição de termos, mas também para a ação e para o diálogo, procedimentos que exigem dos alunos que pensem acerca do significado dos conceitos e com as características essenciais dos fenômenos.

Especialmente no que se refere ao ensino da Biologia, sabe-se que entender e romper com fronteiras muitas vezes concebidas como fixas e que não representam o conhecimento biológico atual, como é o caso do genótipo associado estritamente ao DNA, não é uma mudança conceitual rápida e fácil, demanda a compreensão e assimilação de uma nova visão dos processos biológicos. Conforme já afirmaram Joaquim e El-Hani (2010), não se consegue separar facilmente o gene do DNA, pois esta associação está presente tanto no discurso científico, no âmbito de ensino, como na sociedade.

Acredita-se que tal (re)construção conceitual pode e deve começar nos cursos de formação inicial de professores de Biologia. Uma forma de realizar essa mudança é mediante a problematização de conceitos biológicos, pois conforme afirmam Castro e Carvalho (1992), quando um licenciando chega ao ponto de interrogar o objeto de estudo em sua gênese, buscando as razões ou os motivos que o engendraram, tentando acompanhar as modificações que lhe foram feitas ao longo das diversas incursões através do tempo, ele parece confessar certa disposição para reconstruí-lo. Ou seja, quando ele discute de onde vieram certas ideias, como evoluíram para chegar onde estão, ou mesmo quando questiona os caminhos que geraram tal evolução, de certa forma ele nos dá indícios de que reconhece tais conceitos como objeto de construção e não como conhecimentos revelados ou meramente passíveis de transmissão.

\section{EVIDENCIANDO A RELAC̣ÃO ENTRE GENÓTIPO E FENÓTIPO}

As discussões coletivas no GEBCA sobre a relação genótipo e fenótipo nos permitiram pensar o ensino desses conceitos a fim de possibilitar que os alunos reflitam sobre e problematizem os fenômenos e processos biológicos. Com o intuito de contribuir para a abordagem sistêmica no ensino de Biologia da relação entre genótipo e fenótipo, propõe-se um modelo explicativo (Figura 1) como 
um recurso didático. Neste, salienta-se a centralidade do organismo ao longo do desenvolvimento biológico como o resultado das interações com ele próprio, do fenótipo anterior, do genótipo potencial e do seu ambiente.

Mediante a apresentação do referido modelo explicativo, pretende-se demonstrar que a compreensão da relação entre genótipo e fenótipo depende de: (1) considerar o desenvolvimento do organismo como conceito-chave que necessita ser explicitado; (2) compreender o genótipo como flexível em seu desenvolvimento, tanto em aspectos morfológicos como comportamentais - genótipo potencial; (3) considerar o ambiente físico relevante para um organismo foco, incluindo a herança ambiental e os fatores ambientais aleatórios; (4) conceber o fenótipo como variável ao longo do desenvolvimento e dependente do fenótipo anterior ao momento atual; (5) incluir o organismo como ente ativo que modifica o meio e a ele próprio.

Ao propor a delimitação do organismo como foco, os conceitos de genótipo e fenótipo estão situados dentro de uma vasta rede de conhecimentos e não como conceitos isolados. Salienta-se que para compreender os conceitos de genótipo e fenótipo em uma abordagem que considera as discussões atuais da epistemologia da Biologia, é preciso conceber o organismo como um sistema em que cada parte atua de maneira correlacionada. Portanto, a caixa-preta do desenvolvimento do organismo precisa ser aberta e seus mecanismos de funcionamento explicitados, a fim de que não se constitua em uma limitação de pensamento à compreensão do conhecimento biológico. Esse alargamento conceitual pode levar à (re)construção de conceitos reducionistas, relacionados a gene e a ambiente, em prol de uma visão sistêmica da Biologia, portanto mais integrada, no âmbito da formação inicial de professores dessa disciplina.

Figura 1: Modelo explicativo de rede conceitual envolvendo a relação entre genótipo e fenótipo de um organismo ao longo de sua história de vida.

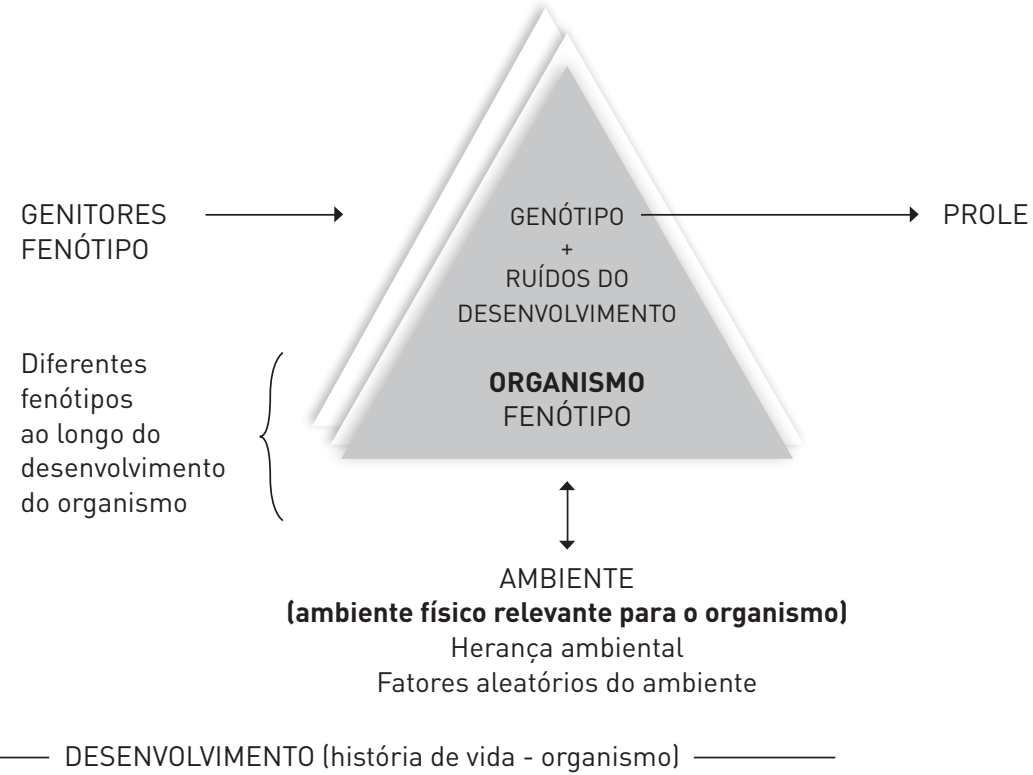




\section{CONCLUSÕES}

Acredita-se que somente com o acesso dos professores em formação inicial a novas ideias e formas de conceber a relação genótipo e fenótipo pode haver a ruptura com o reducionismo da visão genecêntrica, ou DNA-cêntrica, e/ou determinismo ambiental. Nessa perspectiva, os estudos realizados junto ao GEBCA constituíram-se como uma possibilidade de trabalhar a história e epistemologia da Biologia na formação inicial de professores, contribuindo para a inclusão do desenvolvimento do organismo na relação genótipo e fenótipo e, consequentemente, de uma visão mais integrada da Biologia por parte dos acadêmicos participantes da amostra investigada.

Salienta-se que as discussões coletivas em grupos de pesquisa em epistemologia da Biologia, como no caso do GEBCA, podem contribuir para a relação do sujeito com o outro. A mediação produzida nos grupos e a intenção pela busca de um conhecimento mais contextualizado (MALDANER, 2006) permitem que um novo modo de conceber os modelos explicativos dos processos biológicos seja coletivamente construído e, individualmente, significado e internalizado. Assim, os professores em formação inicial estabelecem novas fronteiras de pensamento na compreensão do conhecimento biológico e o seu ensino.

Em relação à análise da evolução conceitual da amostra investigada, observa-se que os participantes apresentavam, inicialmente, ideias próprias de uma visão fragmentada do conhecimento biológico, quando se referiam a conceitos isolados, como por exemplo, no caso de genótipo (é o DNA) e fenótipo (genótipo + ambiente). Em um segundo momento, houve maior referência ao organismo e, de forma gradativa na discussão, a inserção de uma percepção mais sistêmica dos fenômenos biológicos. Durante as discussões coletivas, os estudantes buscaram significar de forma contextualizada os conceitos de genótipo e fenótipo, havendo a inclusão conceitual do organismo e seu desenvolvimento orgânico.

Salienta-se que a problematização de conceitos tidos como verdades/ permanentes possibilita a reconstrução e o alargamento conceitual, estabelecendo novas fronteiras para o pensamento ao concebê-los como provisórios. Relegar o desenvolvimento do organismo ao papel de caixa-preta para a compreensão da relação genótipo e fenótipo evidencia uma ideia equivocada que tem constituído obstáculo epistemológico ao entendimento dos fenômenos biológicos: a de ontogenia concebida como um desdobramento de formas determinadas pelos genes, como sequências de DNA. Embora essa ideia norteie pesquisas científicas e mesmo o conhecimento apresentado no âmbito do ensino de Biologia, há a necessidade de uma mudança, haja vista que a relação entre gene, organismo e ambiente é de interdependência e é mais complexa.

É preciso que os professores de Biologia, em sua formação inicial, compreendam, conforme aponta Tidon (2010), que os organismos não são simples entidades que se encontram adaptados a nichos ecológicos. Pelo contrário, o desenvolvimento dos organismos envolve intrincadas relações entre eles próprios, mas 
também com seus genes e com a sucessão de ambientes nos quais eles se desenvolvem. Também deve ficar claro que a complexidade dessas relações ainda não está bem compreendida pela comunidade científica.

Apesar de o conhecimento sobre as interações ocorridas entre genótipo, organismo e ambiente estar em desenvolvimento na comunidade científica e ser foco de inúmeros debates, buscar esquemas que modelem as discussões atuais sobre biologia sistêmica pode ser um recurso útil para esclarecer e explicitar alguns consensos e ideias que se apresentam na Biologia atual e que são fundamentais para um ensino mais integrado. Nessa perspectiva, o modelo explicativo da complexa relação entre genótipo e fenótipo, proposto no presente artigo, pode ser um recurso útil para a discussão conceitual em Biologia, servindo como base para a elaboração de redes conceituais, com significado contextualizado pelos estudantes. Esse modelo destaca o papel do organismo no conhecimento biológico e se contrapõe aos reducionismos ambientais e genéticos que têm sido, por longo tempo na história da ciência e no ensino de Biologia, obstáculos para uma compreensão da Biologia como ciência integrada, autônoma e com sistemas de ideias interligados.

\section{NOTA}

${ }^{1}$ Pesquisa desenvolvida com o apoio da Fundação Araucária/SETI - Apoio ao Desenvolvimento Científico e Tecnológico do Estado do Paraná.

\section{REFERÊNCIAS BIBLIOGRÁFICAS}

ALMEIDA, A. M. R.; EL-HANI, C. N. Um exame histórico-filosófico de biologia evolutiva do desenvolvimento (evo-devo). Scientiae Studia, São Paulo, 8 (1), p. 9-40, 2010.

ANDRADE, M. A. B. S. A epistemologia da biologia na formação de pesquisadores: compreensão sistêmica de fenômenos moleculares. 2011. 233 f. Tese (Doutorado em Educação para a Ciência) - Faculdade de Ciências da Universidade Estadual de São Paulo (UNESP), Bauru, 2011.

BACHELARD, G. A formação do espirito científico. São Paulo: Contraponto, 1996.

BONZANINI, T. K. Ensino de temas da genética contemporânea: análise das contribuições de um curso de formação continuada. 2011. 252f. volume 1. Tese (Doutorado em Educação para a Ciência). Faculdade de Ciências, da Universidade Estadual de São Paulo (UNESP), Bauru, 2011.

CARVALHO, A. M. P.; GIL-PEREZ, D. Formação de professores de ciências. 9. ed. São Paulo: Cortez, 2009.

CASTRO, R. S.; CARVALHO, A. M. P. História da ciência: como usá-la num curso de segundo grau. Caderno Catarinense de Ensino de Física, Florianópolis, 9 (3), p. 225-237, 1992.

CUNHA, A.M.O. Educação continuada: os professores como mediadores no processo de capacitação. Ensino em Re-vista. Uberlândia, 9(1): 7-24, 2001.

FLICK, U. Introdução à pesquisa qualitativa. 3. ed. Porto Alegre: Artmed, 2009.

FOUREZ, G. Alfabetización cientifica y tecnológica: acerca de las finalidades de la enseñanza de las ciencias, Buenos Aires: Colihue, 1997. 
GUDDING, G. The phenotype/genotype distinction and the disappearance of the body. Journal of the History of Ideas, [s.l], 57 (3) p. 525-545, 1996.

GRIFFITHS, A. J. F. et al. Introdução à genética. 7. ed. Rio de Janeiro: Guanabara Koogan, 2002.

GRIFFITHS, P. E.; GRAY, R. D. Darwinism and developmental systems. In: OYAMA, S.; GRIFFITHS, P. E.; GRAY, R. (ed). Cycles of contingency: developmental systems and evolution. Cambridge, Massachusetts; London, England: MIT Press, 2001. p. 195-218.

JABLONKA, E. The systems of inheritance. In: OYAMA, S.; GRIFFITHS, P. E.; GRAY, R. (ed). Cycles of contingency: developmental systems and evolution. Cambridge, Massachusetts; London, England: MIT Press, 2001. p. 99-116.

JABLONKA, E; LAMB, M. Evolution in four dimensions: genetic, epigenetic, behavioral, and symbolic variation in hystory of life. Cambridge, Massachussets: MIT Press, 2005.

JOAQUIM, L. M.; EL-HANI, C. N. A genética em transformação: crise e revisão do conceito de gene. Scientie Studia, São Paulo, v. 8 (1), p. 93-128, 2010.

JOHANNSEN, W. L. The genotype conception of heredity. The American Naturalist, [s.l], v. 45 (531), p. 129-159, 1911.

JUSTINA, L. A. D. A herança genotípica proposta por Wilhelm Ludwig Johannsen. Filosofia e História da Biologia, São Paulo, 5, p. 55-77, 2010.

JUSTINA, L. A. D.; FERRARI, N. A ciência da hereditariedade: enfoque histórico, epistemológico e pedagógico. Cascavél: Edunioeste, 2010.

LEWONTIN, R. A tripla bélice: gene, organismo e ambiente. São Paulo: Companhia das Letras, 2002.

LORETO. E. L. S.; SEPEL, L. M. N. Programa de incentivo à formação continuada de professores do ensino médio. Santa Maria: Departamento de Biologia da Universidade Federal de Santa Maria (UFSM), 2006. Disponível em: <http://portal.mec.gov.br/seb/arquivos/pdf>. Acesso em: 20 jun. 2010.

MEGLHIORATTI, F. A. O conceito de organismo: uma introdução à epistemologia do conhecimento biológico na formação de graduandos de biologia. 2009. 254 f. Tese (Doutorado em Educação para a Ciência) - Faculdade de Ciências, Universidade Estadual de São Paulo (UNESP), Bauru, 2009.

MEGLHIORATTI, F. A.; EL-HANI, C. N.; CALDEIRA, A. M. A. A centralidade do conceito de organismo no conhecimento biológico e no ensino de biologia. In: Ana Maria de Andrade Caldeira. (Org.). Ensino de Ciências e Matemática II: Temas sobre Formação de Conceitos. São PauloSP: Cultura Acadêmica/ UNESP, 2009, p. 33-52.

MALDANER, O. A. A formação inicial e continuada de professores de quimica: professores/pesquisadores. 3. ed. Ijuí: Unijuí, 2006.

NEUMANN-HELD, E. M. Let's talk about genes: the process molecular gene concept and its context. In: OYAMA, S.; GRIFFITHS, P. E.; GRAY, R. (ed). Cycles of contingency: developmental systems and evolution. Cambridge, Massachusetts; London, England: MIT Press, 2001. p. 69-84.

OYAMA, S.; GRIFFITHS, P. E.; GRAY, R. Introduction: what is developmental systems theory? In: OYAMA, S.; GRIFFITHS, P. E.; GRAY, R. (ed). Cycles of contingency: developmental systems and evolution. Cambridge, Massachusetts; London, England: MIT Press, 2001. p.1-11.

PEDRANCINI, V. D.; CORAZZA, M. J.; GALUCH, M. T. B. Mediação pedagógica e a formação de conceitos científicos sobre hereditariedade. Revista Electrónica de Enseñanza de las Ciencias, Vigo, Espanha, v.10(1): 109-132, 2011.

PERRENOUD, P. Dez novas competências para ensinar. São Paulo: Artes Médicas Sul, 2000.

PORTIN, P. Historical development of the concept of the gene. Journal of Medicine and Philosophy, [s.l], v. 27, p. 257-286, 2002.

SCHNEIDER, E. M. et al. A. Conceitos de gene: construção histórico-epistemológica e percepções de professores do ensino superior. Investigações em Ensino de Ciências, Porto Alegre, v. 16(2), p. 201-222, 2011.

TARDIF, M. Saberes docentes e formação profissional. 7. ed. Petrópolis: Vozes, 2002. 
TIDON, R. Gene, organismo e ambiente. Genética na Escola. Brasilia, v.1 (2), p. 41-44, 2006. Disponível em: <http://www.geneticanaescola.com.br/Ano1vol2.html>. Acesso em: 12 maio de 2010.

TRIVELATO, S.L.F. Perspectivas para a formação de professores. In: TRIVELATO, S.L.F. (org.) Coletânea $3^{a}$ Escola de Verão para Professores de Prática de Ensino de Física, Química e Biologia. São Paulo: FEUSP, 1995. p. 35-48.

Data do Recebimento: $18 / 11 / 2010$

Data de Aprovação: 15/10/2011

Data da Versão Final: 21/11/2011 